\title{
Dietary Factors Influencing the Pathogenesis of Gallstone Disease in Kerala, India
}

\section{ABSTRACT}

Introduction: Increased consumption of meat is associated with gallstone ailment as intake of non-vegetarian food increases biliary acid, a trimethylamine transporter that tempts the gallstone cholesterol.

Aim: To determine the relationship of dietary factors with gallstones amongst Indian patients.

Materials and Methods: The present study was a case-control study which was conducted at Jubilee Mission Medical College Hospital and Research Institute, Thrissur, Kerala, India from February 2008-June 2009. Study population included patients having cholelithiasis or lately identified with indicative or nonindicative gallstones. The nutritional ingestion was measured by qualified nutritionist by means of semi-quantifiable survey on food-frequency questionnaire. The subjects were matched up in age and gender proportions having analogous demographic features. The usual ultrasound of abdomen was performed by medical practitioners.

Results: There were 200 patients included as cases and 200 controls, of the cases 112 (56\%) were males and 88 (44\%) were females, age range was $10-80$ years. Preponderance was noted in age group of 31 to 40 years mounting to 52 (26\%) pursued by $22.5 \%$ controls in the age groups of 21 to 30 and 41 to 50 years. According to the dietary interests, the vegetarian and non-vegetarian percentage ratio was of 21.5 and 78.5.

Conclusion: The risk factors responsible for the development of Gallstone Disease (GSD) were food including meat, cholesterol, tamarind, and squat in fibre. In case of such ailments, vegetarian food with suggested calories and should be encouraged. Therefore, the anticipatory measures like amendments in routine and food should be carried out to eradicate these hazardous factors.

\section{INTRODUCTION}

Cholelithiasis or Gallstone Disease (GSD) portrays significant burden for healthcare structure globally. It is also considered as one of the most common disorders among patients with abdominal discomfort including epigastric pain, nausea, loss of appetite, vomiting etc $[1,2]$. Majority of non-indicative or asymptomatic patients with gallstones, have reported as an accidental finding through scheduled health check-up or for a dissimilar medical problem [3-5]. Currently, gallbladder ailment is a common trouble in developed nations as well as in countries like India [6]. The cause for such diseases might be enormous [7]. GSD is a chronic recurrent hepatobiliary disease, caused by impaired metabolism of cholestrol, bile acids and bilirubin resulting in development of gallstones in the bile duct or gallbladder and hepatic bile duct [8]

Gallstones are chiefly categorised as pigment and cholesterol gallstones; cholesterol gallstones are more than pigment gallstones in western nations as compared to Asian population [9]. Varied and pigment gallstones are very common in the southern region of India [10-13]. While cholesterol gallstones are common in the northern part of the nation [14-17]. In a preceding epidemiological research, it was observed that demographic and social variables do not confer to the composition of pigment gallstone [18]. Expansion of cholesterol gallstones is correlated to infiltration of cholesterol in bile as well as in gallbladder stasis [19]. Pigment gallstones expand from the liberation of $\beta$-glucuronidase [20]. [Table/Fig-1] shows pathogenesis of gallstone formation.

The factors pertaining to nutrition have been measured dominant in many studies, and this is strappingly sustained by the ruling of Pixley $\mathrm{F}$ et al., by means of ultrasonography, which gallstones are only short as ordinary in British vegans as in the rest of the inhabitants [21]. There are numerous dissimilarities amid vegan and regular food. Nevertheless, there is no investigational validation to give away non-vegetarian food.

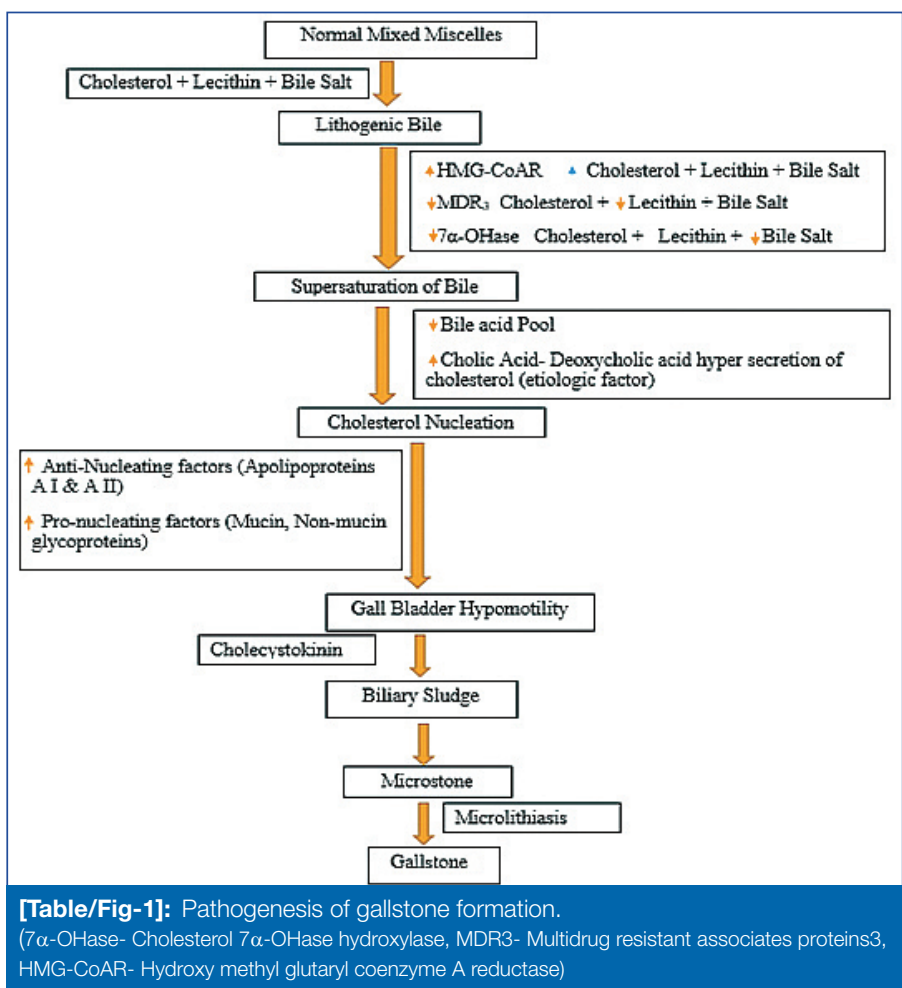

There are several studies which stated that menace of gallstone is surely related to ingestion of non-vegetarian food, vigour, fat and inundated fat. However, it is also connected with ingestion of veggies and fibre in Asian and western inhabitants [22-31]. Predominantly, elevated consumption of meat was connected with hazard of gallstone ailment, as eating of red meat repressed bile acid carriers by trimethylamine which encouraged cholesterol gallstone [22]. Additionally, it has been reported in preceding researches that peril of gallstone was absolutely ingestion of butter, trans fatty acids, 
refined sugars and cooking oil, but unenthusiastically connected with reasonable ingestion of alcohol and coffee in Japanese and Western inhabitants [23,29,32-34]. The peril of gallstone was critically linked with a vigorous nutritional prototype in women from Iran and as well as unconventional Mexican food outlines [35]. The present study was done with an aim to determine the relationship of dietary factors with gallstones amongst Indian patients.

\section{MATERIALS AND METHODS}

This case control study was performed at Jubilee Mission Medical College Hospital and Research Institute, Thrissur, Kerala, India from February 2008-June 2009. Consent was taken from all the participants. Study population consisted of 400 participants, 200 case and 200 controls.

Inclusion criteria: Patients undergoing investigation of gallstone illness having diagnosed as indicative or non-indicative of gallstone disease were included.

Exclusion criteria: Exclusion criteria comprised of patients who underwent open cholecystectomy, biliary drainage procedure, solemn co-morbidity which needed long-term admission to the hospital; and identified with varied gallstones.

The nutritional ingestion was measured by practicing dietician. A semi-quantitative questionnaire was used for the study, that included occurrence of diet particulars, character of cereal used, non-vegetarian diet, monthly oil consumption, sugar consumption per day, tamarind intake per week, and as well as regularity of every day beverage were incorporated in daily food.

The subjects were matched up in age and gender proportions having analogous demographic features. The usual ultrasound of abdomen was performed by medical practitioners.

\section{STATISTICAL ANALYSIS}

The data was collected and analysed by using Chi-Square test and Student's t-test and software for analysis will be SPSS version 20.0 and a p-value $<0.05$ was considered to be statistically significant.

\section{RESULTS}

There were 200 patients included in the study as well as there were 200 controls for the analysis. Out of total, 112 (56\%) were males and the rest 88 (44\%) were females, with age ranging from 1080 years. Preponderance of cases were noted in the age group were of 31 to 40 years- 52 (26\%) [Table/Fig-2] followed by 22.5\% controls in the age groups of 21 to 30 and 41 to 50 years. According to the dietary interests, the vegetarian and non-vegetarian percentage was of $21.5 \%$ (43) and 78.5 (157) [Table/Fig-3].

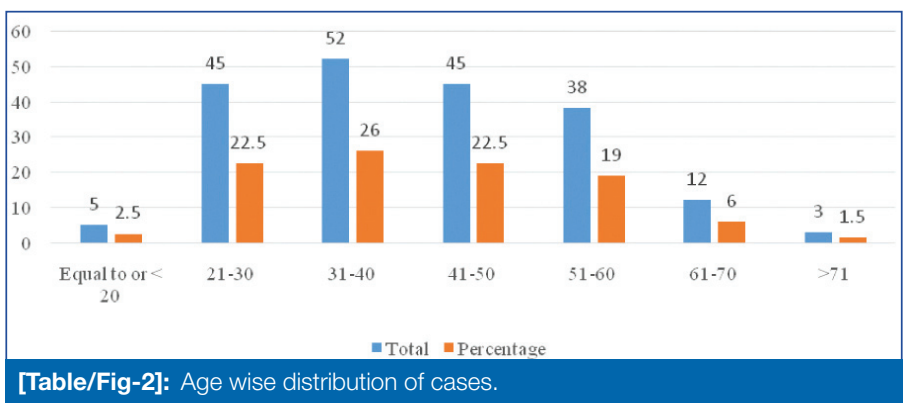

There was no dietary parameter difference observed between controls and cases. A comparison has been made in [Table/Fig-4] on cases and controls which are equal in numbers. It was found that age was parallel in both the groups i.e., $38.6 \pm 8.4$ vs $42.58 \pm 6.8$ (years) in cases and controls correspondingly.

Consumption of distinct diets was usually dispersed and allocation was analogous in both i.e., cases and controls while making an allowance for dietary intake for non-vegetarians and vegetarians. However, dissimilarities appeared as displayed in the [Table/Fig-5].
A total of $95 \% \mathrm{Cl}$ for gallstone ailment as per the nutritional outline sort is displayed in [Table/Fig-6].

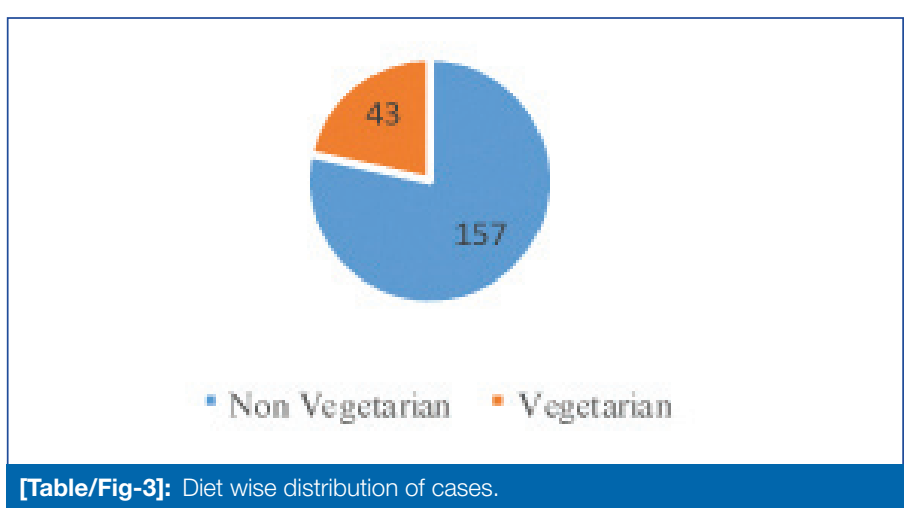

\begin{tabular}{|c|c|c|c|c|}
\hline $\begin{array}{l}\text { S. } \\
\text { No. }\end{array}$ & Factors & $\begin{array}{l}\text { Cases } \\
\mathrm{N}(200)\end{array}$ & $\begin{array}{l}\text { Controls } \\
N(200)\end{array}$ & $\begin{array}{c}\mathrm{p}- \\
\text { value }\end{array}$ \\
\hline 1 & Age (years) & $38.6 \pm 8.4$ & $42.58 \pm 6.8$ & 0.34 \\
\hline 2 & Body mass index $\left(\mathrm{kg} / \mathrm{m}^{2}\right)$ & $27.03 \pm 5.2$ & $26.83 \pm 4.1$ & 0.053 \\
\hline \multirow{5}{*}{3} & Marital Status & & & \multirow{5}{*}{0.005} \\
\hline & Single & $20(10 \%)$ & $6(3 \%)$ & \\
\hline & Married & $161(80.5 \%)$ & $172(86 \%)$ & \\
\hline & Divorced & $06(3 \%)$ & $07(3.5 \%)$ & \\
\hline & Widowed & $13(6.5 \%)$ & $15(7.5 \%)$ & \\
\hline \multirow{3}{*}{4} & Family obesity & & & \multirow{3}{*}{0.5} \\
\hline & Yes & $113(56.5 \%)$ & 99 (49.5\%) & \\
\hline & No & $87(43.5 \%)$ & $101(50.5 \%)$ & \\
\hline 5 & Energy Intake (kcal/day) & $2736.6 \pm 665$ & $2579 \pm 672$ & 0.028 \\
\hline 6 & No. of meals per day (>3/day) & $53(26.5 \%)$ & $44(22 \%)$ & 0.031 \\
\hline 7 & Non-vegetarian food (>3 times/week) & 145 (72.5\%) & $152(76 \%)$ & 0.5 \\
\hline 8 & Egg & $116(58 \%)$ & $102(51 \%)$ & 0.5 \\
\hline 9 & Whole grains & $138(69 \%)$ & $143(71.5 \%)$ & 0.45 \\
\hline 10 & Tamarind $>3$ times/week & $187(93.5 \%)$ & $172(86 \%)$ & 0.03 \\
\hline 11 & Nuts & $143(71.5 \%)$ & $135(67.5 \%)$ & 0.41 \\
\hline 12 & Oil $>500 \mathrm{~mL} / \mathrm{month}$ & $134(67 \%)$ & $132(66 \%)$ & 0.7 \\
\hline 13 & Vegetables & $156(78 \%)$ & $153(76.5 \%)$ & 0.73 \\
\hline 14 & Fruits & 109 (54.5\%) & $102(51 \%)$ & 0.6 \\
\hline 15 & Cereals: Wheat/combination & $112(56 \%)$ & $96(48 \%)$ & 0.06 \\
\hline 16 & Sugar/day $>20$ g/day & $157(78.5 \%)$ & $160(80 \%)$ & 0.87 \\
\hline 17 & Quantity of beverage (>3 cups/day) & $57(28.5 \%)$ & $61(30.5 \%)$ & 0.5 \\
\hline \multirow{5}{*}{18} & Type of beverage & & & \multirow{5}{*}{0.5} \\
\hline & None & $10(5 \%)$ & $12(6 \%)$ & \\
\hline & Tea & $82(41 \%)$ & $91(45.5 \%)$ & \\
\hline & Coffee & $59(29.5 \%)$ & $52(26 \%)$ & \\
\hline & Milk & $49(24.5 \%)$ & $45(22.5 \%)$ & \\
\hline
\end{tabular}
$p$-value $<0.05$ was considered to be statistically significant

\section{DISCUSSION}

According to this study, there are many dietary causes that are very significant in the aetiology of gallstones. Predominantly, a high intake of drenched fats and refined sugar can possibly amplify the risk of gallstone configuration, while an elevated ingestion of saturated fats, and nutritional cholesterol might guard against gallstone creation. Furthermore, the risk of cholesterol gallstone was connected with nutritional prototype having pork, fried food; beef etc., whereas there was no relationship between menace of pigment gallstone and nutritional model. The function of dietary factors in cholesterol gallstones has been described by many authors [36,37]. The chief hazard issue incorporated drawn out fasting, low-calorie diet, stoutness, edible oil, refined sugar and high calorie intake [38-42]. 


\begin{tabular}{|l|l|c|c|c|}
\hline $\begin{array}{l}\text { Sl. } \\
\text { No. }\end{array}$ & \multicolumn{1}{|c|}{ Nutrients } & Vegetarians & $\begin{array}{c}\text { Non- } \\
\text { vegetarians }\end{array}$ & p-value \\
\hline 1 & Total calories (Kcal) & 2183 & 2472 & 0.001 \\
\hline 2 & Total protein (g) & 42.2 & 65 & 0.001 \\
\hline 3 & Protein (\% energy) & 11.6 & 15.3 & 0.001 \\
\hline 4 & Animal protein (g) & 0.3 & 28.4 & 0.001 \\
\hline 5 & Animal product protein (g) & 18.3 & 21.2 & NS \\
\hline 6 & Alcohol (g) & 5.6 & 9.1 & 0.001 \\
\hline 7 & Refined sugars (g) & 94.4 & 80.4 & 0.001 \\
\hline 8 & Refined sugars (\% energy) & 23.5 & 18.2 & 0.001 \\
\hline 9 & Total carbohydrate (g) & 247.6 & 201.3 & 0.001 \\
\hline 10 & Carbohydrate (\% energy) & 56.3 & 47.2 & 0.001 \\
\hline 11 & Nonanimal protein (g) & 27.1 & 17.8 & 0.001 \\
\hline 12 & Fat (\% energy) & 35.7 & 46.1 & 0.001 \\
\hline 13 & Total fat (g) & $69.8)$ & 91.4 & 0.001 \\
\hline 14 & Cholesterol (mg) & 182.6 & 358.3 & 0.001 \\
\hline 15 & Fibre (g) & 27.9 & 18.4 & 0.001 \\
\hline [Table/Fig-5]: Intake of total energy and various nutrients in nonvegetarians and \\
vegetarians. \\
NS: Non significant; p-value <0.05 was considered to be statistically significant
\end{tabular}

\begin{tabular}{|c|c|c|c|c|}
\hline Dietary pattern & $\begin{array}{c}\text { Cases No. } \\
(\%)\end{array}$ & $\begin{array}{c}\text { Controls No. } \\
(\%)\end{array}$ & OR (95\% Cl) & $p$-value \\
\hline \multicolumn{4}{|l|}{ Healthy } & \multirow{3}{*}{$<0.001$} \\
\hline High & $80(40 \%)$ & 118 (59\%) & 1.00 & \\
\hline Low & $120(60 \%)$ & $82(41 \%)$ & $0.17(0.052-0.46)$ & \\
\hline \multicolumn{4}{|l|}{ Unhealthy } & \multirow{3}{*}{0.005} \\
\hline High & $163(81.5 \%)$ & $64(32 \%)$ & 1.00 & \\
\hline Low & 37 (18.5\%) & 136 (68\%) & $4.21(1.82-9.49)$ & \\
\hline
\end{tabular}

Obesity was established as an imperative jeopardy reason for gallstones verifying the conclusion of numerous studies done previously [43-46].

Gallstone ailment is caused by deposit of hard fat or mineral in the gallbladder. In this ailment, the stones block part of biliary mechanism and create exasperation of gallbladder and difficulties. This disarray can source life intimidating circumstances, if left untreated [47]. The ingestion of food (non-vegetarian or vegetarian) does not influence the incidence of gallstones $[16,48]$. This study has displayed a noteworthy alliance between intake of tamarind more than three times a week and the incident of gallstones ailment. Consumption of oil too did not influence gallstone ailment. Population of Kerala consume beverages like tea and coffee in high amount; however, this did not lead to gallstone ailment by exciting for the emission of cholecystokinin causing increased gallbladder motility. Intake of sugar was also not causative. Though, there is an inspection of less than $15 \mathrm{~g}$ sugar consumption per day being connected with advanced peril for gallstone ailment $[29,43]$.

This study found an enlarged menace of GSD with towering ingestion of solid fat, non-vegetarian food, and egg within the damaging nutritional outline structure. There are many studies which have displayed an elevated total fat and saturated fat consumption among patients with cholelithiasis and propose an aetiological role for these nutritional mechanism [49,50]. There are many researches that have recommended that red meat and egg-yolk animal protein, animal fat as well as nutritional cholesterol augment the biliary cholesterol saturation and encourage cholesterol gallstones, which is also established in this work [48, 51-56]. New perspectives for a better understanding of the role of dietary constituents on cholesterol gallstone formation have been unfastened in latest findings of the role of orphan nuclear receptors in the regulation of fatty acid and hepatic cholesterol metabolism and emission [57].

\section{Limitation(s)}

This study had small sample size. Prospective study with a larger population are required, under strict supervisions of subjects these perspectives would have better understanding of the role of dietary factors for the gallstone formation and gallstones diseases.

\section{CONCLUSION(S)}

There is no single responsible factor for gallstone ailment as it is caused by various reasons. Food intake is a major hazard aspect for illness however, it can be tailored in the interest of the individual. Therefore, the current work emphasises upon a number of nutritional features which manipulates the gallstone ailment and modifies in food habit to assist with indications of gallstones and anticipation. The risk factors responsible for the development of GSD were food including meat, cholesterol, tamarind, and high in fibre. In case of such ailments, vegetarian food with suggested calories should be encouraged. Therefore, the anticipatory measures like amendments in routine and food should be carried out to eradicate these hazard factors.

\section{REFERENCES}

[1] Hung SH, Liao KF, Lai SW, Li Cl, Chen WC. Risk factors associated with symptomatic cholelithiasis in Taiwan: A population-based study. BMC Gastroenterol. 2011;11:111-16.

[2] Chen LY, Qiao QH, Zhang SC, Chen YH, Chao GQ, Fang LZ. Metabolic syndrome and gallstone disease. World J Gastroenterol. 2012;18:4215-20.

[3] Beckingham IJ. ABC of diseases of liver, pancreas, and biliary system. Gallstone disease. Br Med J. 2001;322:91-94

[4] Attili AF, Carulli N, Roda E, Barbara B, Capocaccia L, Menotti A, et al. Epidemiology of gallstone disease in Italy: Prevalence data of the Multicente Italian Study on Cholelithiasis (MICOL). Am J Epidemiol. 1995;141:158-65.

[5] Heaton KW, Braddon FE, Mountford RA, Hughes AO, Emmett PM. Symptomatic and silent gall stones in the community. Gut. 1991;32:316-20.

[6] Pedersen G, Hoem D, Sandberg A. Influence of laparoscopic cholecystectomy on the prevalence of operations for gallstones in Norway. Eur J Surg. 2002;168:464-69.

[7] Conte D, Fraquelli M, Giunta M, Conti CB. Gallstones and liver disease: An overview. J Gastrointestin Liver Dis. 2011;20:09-11.

[8] Belousov Yu V. Pediatric Gastroenterology. Up-to-date guide. Moscow: Exma 2006: 112.

[9] Stringer MD, Fraser S, Gordon KC, Sharples K, Windsor JA. Gallstones in New Zealand: Composition, risk factors and ethnic differences. ANZ J Surg. 2013;83(7-8):575-80.

[10] Jayanthi V. Pattern of gallstone in Madras city, southern India- A hospital based survey. J Assoc Physicians India. 1996;44:461-64.

[11] Jayanthi V, Palanivelu C, Prasanthi R, Mathew S, Srinivasan V. Composition of gallstones in Coimbatore district of Tamil Nadu state. Indian J Gastroenterol. 1998; 17:134-35.

[12] Gokulakrishnan S, Murugesan R, Mathew S, Prasanthi R, Ashok AC, Ramesh $\mathrm{H}$, et al. Predicting the composition of gallstones by infrared spectroscopy. Trop Gastroenterol. 2001;22:87-89.

[13] Ananthakrishnan N. Current concepts in the pathogenesis of gallstones. Indian J Surg. 1998;60:85-89. http://www.indianjgastro.com/IJG_pdf/july1998/8789.pdf.

[14] Sarin SK, Kapur BML, Tandon RK. Cholesterol and pigment gallstones in northern India. A prospective analysis. Dig Dis Sci. 1986;31:1041-45.

[15] Agarwal DK, Choudhuri G, Rao KV, Saxena R, Kapoor VK. Gallstone composition in North Indian population- Changing pattern (Abstract). Indian J Gastroenterol. 1991;10 (Suppl):A14.

[16] Singh V, Trikha B, Nain C, Singh K, Bose SJ. Epidemiology of gallstone disease in Chandigarh: A community-based study. Gastroenterol Hepatol. 2001;16:560-63.

[17] Kotwal MR, Rinchen CZ. Gallstone disease in the Himalayas (Sikkim and northern Bengal): Causation and stone analysis. Indian J Gastroenterol. 1998; $17: 87-89$

[18] Jayanthi V, Prasanthi R, Sivakumar G, Surendran R, Srinivas U, Mathew S, et al. Epidemiology of gallstone disease- Topline findings. Bombay Hosp J. 1999;41:494-502.

[19] Gustafsson U, Sahlin S, Einarsson C. Biliary lipid composition in patients with cholesterol and pigment gallstones and gallstone-free subjects: Deoxycholic acid does not contribute to formation of cholesterol gallstones. Eur J Clin Investig. 2000;30(12):1099-106.

[20] Maki T. Pathogenesis of calcium bilirubinate gallstone: Role of E. coli, betaglucuronidase and coagulation by inorganic ions, polyelectrolytes and agitation. Ann Surg. 1966;164(1):90-100.

[21] Pixley F, Epidemiology. In: Gallstone Disease and Its Management (M.C. Bateson, ed.), Lancaster: MTP Press; 1986:01-23.

[22] Ortega RM, Fernandez-Azuela M, Encinas-Sotillos A, Andres P, Lopez-Sobale AM. Differences in diet and food habits between patients with gallstones and controls. J Am Coll Nutr. 1997;16(1):88-95. 
[23] Misciagna G, Centonze S, Leoci C, Guerra V, Cisternino AM, Ceo R, et al. Diet, physical activity, and gallstones-A population-based, case-control study in southern Italy. Am J Clin Nutr. 1999;69(1):120-26.

[24] Compagnucci AB, Perroud HA, Batalles SM, Villavicencio R, Brasca A, Berli D, et al. A nested case-control study on dietary fat consumption and the risk for gallstone disease. J Hum Nutr Diet. 2016;29(3):338-44.

[25] Tsai CJ, Leitzmann MF, Willett WC, Giovannucci EL. Fruit and vegetable consumption and risk of cholecystectomy in women. Am $\mathrm{J}$ Med. 2006;119(9):760-67.

[26] Nordenvall C, Oskarsson V, Wolk A. Fruit and vegetable consumption and risk of cholecystectomy: A prospective cohort study of women and men. Eur J Nutr. 2016. Doi: 10.1007/s00394-016-1298-6.

[27] Kameda H, Ishihara F, Shibata K, Tsukie E. Clinical and nutritional study on gallstone disease in Japan. Jpn J Med. 1984;23(2):109-13.

[28] Tsai CJ, Leitzmann MF, Willett WC, Giovannucci EL. Long-term intake of dietary fiber and decreased risk of cholecystectomy in women. Am J Gastroentero. 2004;99(7):1364-70.

[29] Jorgensen T, Jorgensen LM. Gallstones and diet in a Danish population. Scand J Gastroenterol. 1989;24(7):821-26.

[30] Davidovic DB, Tomic DV, Jorg JB. Dietary habits as a risk factor of gallstone disease in Serbia. Acta Chirlugosl. 2011;58(4):41-44.

[31] Shin Y, Choi D, Lee KG, Choi HS, Park Y. Association between dietary intake and post laparoscopic cholecystectomic symptoms in patients with gallbladder disease. Korean J Intern Med. 2017. Doi: https://doi.org/10.3904/ kjim.2016.223

[32] Tsai CJ, Leitzmann MF, Willett WC, Giovannucci EL. Long-term intake of trans-fatty acids and risk of gallstone disease in men. Arch Intern Med. 2005;165(9):1011-15

[33] Moerman CJ, Smeets FW, Kromhout D. Dietary risk factors for clinically diagnosed gallstones in middle-aged men. A 25-year follow-up study (the Zutphen study). Ann Epidemiol. 1994;4(3):248-54.

[34] Caroli-Bosc FX, Deveau C, Peten EP, Delabre B, Zanaldi H, Hebuterne X, et al. Cholelithiasis and dietary risk factors: An epidemiologic investigation in Vidauban, Southeast France. General Practitioner's group of Vidauban. Dig Dis Sci. 1998;43(9):2131-37.

[35] Tseng M, DeVellis RF, Maurer KR, Khare M, Kohlmeier L, Everhart JE, et al. Food intake patterns and gallbladder disease in Mexican Americans. Public Health Nutr. 2000;3(2):233-43.

[36] Sarles H, Hauton J, Plache NE, Lafont H, Gerolami A. Diet, cholesterol gallstone and composition. Am J Dig Dis. 1970;15:251-60.

[37] Sarles H, Gerolami A, Board A. Diet and cholesterol gallstones: A further study. Digestion. 1978;17:128-31.

[38] Sichieri R, Everhart JE, Roth HA. Prospective study of hospitalization with gallstone disease among women: Role of dietary factors, fasting period, and dieting. Am J Public Health. 1991;81:880-84.

[39] Leitzmann MF, Willett WC, Rimm EB, Stampfer MJ, Spiegelman D, Colditz GA, et al. A prospective study of coffee consumption and the risk of symptomatic gallstone disease in men. JAMA. 1999;281:2106.
[40] Lamri-Senhadji MY, Mekki K, El Kebir B, Bachir-Bouiadjra N, Bouchenak M, Belleville. Effect of dietary consumption, advanced age and overweight on the physical characteristics of cholesterol gallstones and biliary lipid composition in west Algerian women. J Ann Nutr Metab. 2002;46:139-46.

[41] Dowling RH. Cholelithiasis: Medical treatment. Clinics in Gastroenterology. 1982;12:125-77.

[42] Thornton JR, Emmet P, Heaton KW. Diet and gallstones: Effects of refined and unrefined carbohydrate diet on bile cholesterol saturation and bile acid metabolism. Gut. 1983;24:02-06.

[43] Scragg RKR, McMichael AJ, Baghurst PA. Diet, alcohol and relative weight in gallstone disease: A case-control study. Br Med J. 1984;288:1113-19.

[44] Pixley FJ, Wilson DJ, McPherson K, Mann Jl. Effect of vegetarianism on development of gallstones in women. Br Med J. 1985;291:11-12.

[45] Rome Group for the epidemiology and prevention of cholelithiasis. Prevalence of gallstone disease in an Italian adult female population. Am J Epidemiol. 1984;119:796-805.

[46] Friedman GD, Kannel WB, Dawber TR. The epidemiology of gallbladder disease: Observations in the Framingham study. J Chronic Dis. 1966;19:273-92.

[47] Huang L, Zhao A, Lew JL, Zhang T, Hrywna Y, Thompson JR, et al. Farnesoid $\mathrm{X}$-receptor activates transcription of the phospholipid pump MDR3. J Biol Chem. 2003;278(51):51085-90.

[48] Tandon RK, Saraya A, Paul S, Kapur BML. Dietary habits of gallstone patients in northern India. J Clin Gastroenterol. 1996;22:23-27.

[49] Yago MD, González V, Serrano P, Calpena R, Martínez MA, MartínezVictoria E, et al. Effect of the type of dietary fat on biliary lipid composition and bile lithogenicity in humans with cholesterol gallstone disease. Nutrition. 2005:21:339-47.

[50] Sarles H, Chabert C, Pommeau Y, Save E, Mouret H, Gérolami A. Diet and cholesterol gallstones. A study of 101 patients with cholelithiasis compared to 101 matched controls. Am J Dig Dis. 1969:14:531-37.

[51] Pastides H, Tzonou A, Trichopoulos D, Katsouyanni K, Trichopoulou A, Kefalogiannis $\mathrm{N}$, et al. A case-control study of the relationship between smoking, diet, and gallbladder disease. Arch Intern Med. 1990;150:1409-12.

[52] Linos AD, Daras V, Linos DA, Kekis V, Tsoukas MM, Golematis V. Dietary and other risk factors in the aetiology of cholelithiasis: A case control study. HPB Surg. 1989;1:221-27.

[53] Worthington HV, Hunt LP, McCloy RF, Ubbink JB, Braganza JM. Dietary antioxidant lack, impaired hepatic glutathione reserve, and cholesterol gallstones. Clin Chim Acta. 2004;349:157-65.

[54] Grundy SM, Mok HYI. Effect of diets and drugs on biliary cholesterol secretion in man. In: Fisher MM, Goresky CA, Shaffer EA, Strasbert FM, editors. Gallstones. New York, NY: Plenum, 1979:238-98

[55] DenBesten L, Connor WE, Bell S. The effect of dietary cholesterol on the composition of human bile. Surgery. 1973;73:266-73.

[56] Van der Linden W, Bergman F. Formation and dissolution of gallstones in experimental animals. Int Rev Exp Pathol. 1977:17:173-233.

[57] Cuevas A, Miquel JF, Reyes MS, Zanlungo S, Nervi F. Diet as a risk factor for cholesterol gallstone disease. J Am Coll Nutr. 2004;23(3):187-96.

PARTICULARS OF CONTRIBUTORS:

1. Associate Professor, Department of Surgery, Sreenarayana Institute of Medical Sciences, Ernakulam, Kerala, India.

NAME, ADDRESS, E-MAIL ID OF THE CORRESPONDING AUTHOR:

Dr. TG Raghu,

Associate Professor, Department of Surgery, Sreenarayana Institute of Medical Sciences,

P.O. Chalakka, Ernakulam District-683594, Kerala, India.

E-mail: drmeenakshitripathi1@gmail.com

\section{AUTHOR DECLARATION:}

- Financial or Other Competing Interests: None

- Was Ethics Committee Approval obtained for this study? No

- Was informed consent obtained from the subjects involved in the study? Yes

- For any images presented appropriate consent has been obtained from the subjects. NA
PLAGIARISM CHECKING METHODS: JJain Het al.]

- Plagiarism X-checker: Aug 08, 2020

- Manual Googling: Oct 07, 2020

- iThenticate Software: Jan 13, 2021 (14\%)
ETYMOLOGY: Author Origin

Date of Submission: Aug 06, 2020

Date of Peer Review: Sep 09, 2020

Date of Acceptance: Oct 11, 2020

Date of Publishing: Apr 01, 2021 